\title{
The Mechanics of Time in Confrontation with the Poet and the Physicist in Jayanta Mahapatra's Poetry
}

\author{
Sreekanth Kopuri
}

\begin{abstract}
A physicist in a ceaseless confrontation with the mysterious cycles of time beyond the life's mortal periphery, Jayanta Mahapatra, as also a poet, experiments with their mechanics which are influenced by both his profession and his Christian-Hindu faith. He gleans his fragmented self that is clustered in the painful absence beyond, behind him. Collecting the self from memories in a clockwise introspection in terms of circular motion of time and trying to understand it well in terms of Alexander Pope's view, "know then thyself presume not God to scan" [1] (Griffin 1978: 152), Jayanta Mahapatra searches for a meaning in human existence with the consciousness of Einstein's words "A spirit is manifest in the laws of universe." [2] (Schneider 2013: 9). A major contemporary experimental voice in Indian English Literature, Mahapatra represents India on the international threshold with a native fragrance in the portrayal of every fragment of his indigenous landscape and language. The dual personality in him examines its self through the linear and circular motions of time. In the ubiquitous vacillation in his poetry between the two standpoints, of time the two disciplines science and poetry - relentlessly collide and leave behind a trajectory of hypnagogic images towards a search for a new metaphor to widen the scope and dimension of the post modern poetry. The bleakness of future on the other hand observed through the linear movement of time magnifies the recurring uncertainty which strongly establishes that man is but a speck in the unfathomably large universe evoking Stephen Hawking's words, "God ......plays dice with the universe" [3] (Larsen 2005: 42) - a counter to those of Albert Einstein's, "God does not play dice with the universe" [4] (Mills 2006: 100) on the theory of Quantum Mechanics. So his poetry opens a dialogue with science which is a kind of holistic approach towards life.
\end{abstract}

Index Terms - Time mechanics, circular movement, linear movement, Christian, holistic.

\section{INTRODUCTION TO SPACE AND TIME}

"The first problem of man was to find his way about on the Earth" [5] (Born 1962: 5).

Every entity, irrespective of the minutest atom, is framed in more or less a limit of time. The mission of man depends upon the limit of time fixed behind him which consciously or unconsciously stimulates his complete substance to bring out a legacy. Tradition, beliefs and many other influences, from cradle to grave, mould one's time with chosen amendments, sifting the others which sometimes stand as mutual obstacles. The strength and operation of one's spiritual and intellectual powers expand within the set time frame rather restlessly for an identity that "the beating of the heart makes one impatient,

Manuscript received April 25, 2016; revised September 3, 2016.

Sreekanth Kopuri is with the Sri Vasavi Institute of Engineering \& Technology, India (e-mail: sreekanthkopuri@gmail.com). one becomes / a little child who is hurt not only by a word, / but by a short pause of indecision" [6] (Mahapatra 1992: 14). They agitate to establish the individual. Man is a potential space of time within which his life is cleft into two phases being and becoming. Time ultimately leans towards eternity. Time is related to the deeds and history of the individual's past. Conditional, its equations change by the faith and action. Space of life expands and contracts according to the variations of time by the velocity of deeds.

\section{CONCEPTUAL BACKGROUND OF JAYANTA MAHAPATRA}

What does time mean in Jayanta Mahapatra's Poetry? What is its outcome and what ideal does his experience bring? It is important to look into a brief background to Mahapatra's life. Born into a Brahmin family; strongly influenced by his mother's staunch Christian upbringing and his grandfather's conversion to Christianity at the time of great famine; the Christian influence of his wife Runu; long agitated by the enigmatic equilibrium of hidden power behind creation and the annoying supremacy of "that something called God" and all this scientific mystery, which he learnt as a trained physicist defeat him into solitude where his quest for identity starts. About his cleft identity which inculcates an innovative poetic technique Sreekanth Kopuri writes:

Operating the technique with symbols, metaphors, motifs and implications as de-creative devices, he enwraps in them the vociferous tones of angst about the recurring mysteries around, the three-fold compromise (between science and literature, Hinduism and Christianity, and life and death) with a cleft identity and the nostalgical defeat into the time present, in the densest form. He draws the present absence as the figures of deprivation engulfing them with the contours of burdensome presence. [7] (Kopuri 2014: 125).

He resorts himself in every fragment of landscape of Odissa and searches for his identity. His existence is engulfed by the "laws of binary opposition" [8] (Roughley 1999: 92). The spiritual agitation is obvious on the surface of his native landscape where the natural metaphoric excellence, typical of his own style, tunes his vociferous tones of indecisiveness. Of this he draws a lyrical image in which "most heterogeneous ideas are yoked together by violence" [9] (Himant 1994: 203), two faiths between which he was brought up claim him and drag him into agitation:

Those sad pigeons beneath temple arcades.

Everyone looks one is stirred by skies [10] (Mahapatra 1997: 72). 


\section{INTERPRETATION OF THE MECHANICS OF TIME}

Time in Mahapatra's life is influenced by his profession as a physicist and faith as a Christian turned Hindu, the consequent impact of which makes him confront with, in the words of Coleridge, "all things both great and small" around him. Even a mundane object has a meaning in his poetry and is split in terms of time. Finally in Mahapatra's poetry time mechanics unconsciously merge into the Christian ones. Sin is the origin of time for man. It shaped him with mortality. The part one of Mahapatra's Random Descent titled, "Old Violins of Legends", opens with the poem "Genesis" which is symbolic of Biblical origins of sin and mortality of human being. The poem is allusive of the opening lines of Paradise Lost,

\section{Of man's first disobedience and the fruit \\ Of that forbidden tree, whose mortal taste \\ Brought death into the world, [11] (Milton 2005: 1).}

Mahapatra's poem opens with a juxtaposition of time and eternity (the images of both heaven and earth) in Christian point of view. The symbols "apple" and "bed" denote the things of God's test to man's obedience to him. And the poem also has a connotation of the first murder on the Earth, the murder of Abel by his brother Cain and an obviously parallel contemporary connotation to the communal riots in Gujarat. And in the question that follows in the poem we can see the poet's inescapable contemplation of time that follows the first two sins of man which shapes his destiny. The lines read:

\section{The apple sits on an old examination bed in the world's foyer.}

\section{The stony silence of the men staring hard} crosses the line of sanity.

\section{Why do I think of this,}

drowned in the depth of lost time? [12] (Mahapatra 2005: 13).

The thought process of Mahapatra is very deep and implies many things of higher order. The simple lines split into a sudden transcendental depth as if the poet is startled by a sudden strange experience. The phrase "lost time" also indicates the disinheritance of man from the world of eternity and immortality since the consumption of the forbidden fruit. The line "apple sits on the examination bed" symbolizes that one must set the "apple" episode on the examination bed again and re-think in a contemporary point of view to understand the philosophical concept of time. The "apple" episode according to Mahapatra is a kind of "big band" which led to the mortal transformation of time allotted to man in the beginning. This image of examination bed is also allusive of T.S.Eliot's famous line "like a patient etherized upon a table" [13] (Beech 2003: 40) in the poem "Love Song of J. Alfred Prufrock."

His encounters with the landscape around him and the suffering of the people place him in a complex encounter with the visible and invisible; the known and the unknown mechanics of time. Consequently the poetry also breaks into surrealistic crisscrosses. Bruce King Says:

\section{It consists of juxtaposed images and statements \\ Contrasting particulars and generalizations opposing \\ Description and moods [14] (King 2008: 1).}

\section{MAHAPATRA'S EINSTEN-HAWKING VIEWS Of TIME}

In the poem, "Traveller" the poet describes his comparative experience. He observes a daily ritual in a temple where he sees the "bells rest their easy weight on the bones", by which he means a ritualistic practice of devotees ringing the temple bell in which the "easy weight" of the bell rests "on the bones." This is an encounter between time and eternity where the music of life is symbolized by the sound of bell and the silence of the dead by the image of bones. This can be interpreted as a physicist's philosophical intrigue with the Einsteinian truth related to Quantum Mechanics in the words "God does not play dice with the universe" which mean that the ends of everything evolve from the laws that are already formulated by God. This is related to the biblical truth that the idolaters will perish. So the image in the poem refers to the Hindu practice of expressing reverence by ringing the bell in a temple during their prayer which according to the poet is contrary to his faith. This contradiction specifies the variation of time in the post-creative episode. It also has a sarcastic connotation that the land of Orissa is pregnant with the human bones of the Kalinga war. He writes:

\section{Every evening \\ the bells of the temple close by \\ rest their easy weight on the bones; \\ it's time again to wonder \\ what I'll do with what I learn. [12] (21).}

The poet further metaphorises his expression with a small image to express his agnostic view when he couldn't come to a logical end. The poem presents the poet's philosophical confrontation with the continuous presence of many mysterious movements which baffle him in spite of his learning many things as a physicist. He gives up saying:

\section{A warm vapor rises \\ from the darkening earth like a hope. [12] (21).}

This view of the poet is related to another concept of physics opposite to Einstein's words said by Stephen Hawking, "God not only plays dice, he also sometimes throws the dice where they cannot be seen" meaning that "in quantum mechanics nothing is certain" [15] (Gribbin 1987: 44) which the phrase "darkening earth" refers to and "warm vapor" his understanding. Throughout his pursuits in the poetry of Jayanata Mahapatra, there is a philosophical dilemma about the truth of everything examined in the light of the mechanics of time.

He tries to quiet himself but in him "something there is that doesn't love a wall / That sends the frozen ground swell under it" [16] (Betty 2000: 14). There are innumerable movements 
around man. And every movement here has purpose. The intensity and the duration of their time vary and are relative and it is these secrets which the entire poetry of Mahapatra searches for. His agitated and scattered self; that was lost in the irredeemable depths of time dwells in every sundry movement of creation. But he in the end finds himself always defeated by the tightening grip of something around every movement. Nature, for him, somehow seems to find the secret and becomes silent unlike the poet who too becomes silent but in defeated and withdrawn tones submitting himself to something that controls every movement of life. In a defeated tone he says:

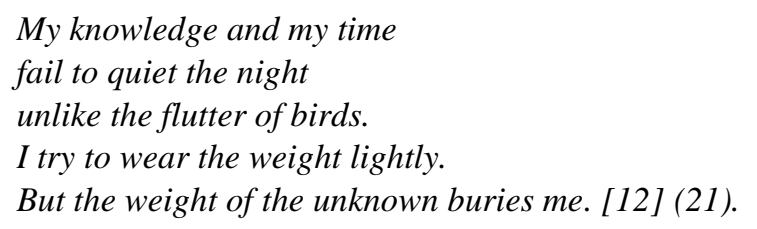

But the poet's quest for the self passionately continues into the domains of absence because,

.... whatever grows from this absence (75).

Is the destiny ...(he)..... feel (s)....(he)... shall share. [10]

\section{LINEAR AND CIRCULAR MOVEMENTS OF TIME}

He finds the old deposits of his self in memories and history and to understand himself better and re-examine the life for an alternative possibility to reach the truth, he gathers his memories to shape a complete and true self. In the process he also looks deep into present life and the ongoing practices and tries to understand his self in his belief of the things. This quest takes him through analytical parameters of time, the dynamics of which are circular and linear of which circular is for introspection and linear is for progression. While introspecting, he moves through different fragments of landscape which sometimes are only images of past where he painfully embraces those nostalgic remains of landscape suddenly dropping into the present and visualizing the future. The poem "Defeat" is a knit of three contours — past, present and future. The move of imagination starts "as a child on...(his)... way to school" where he watches the fire crackle in blacksmith's shop where a boy sits smiling and fanning the flames. He says:

I didn't notice his eyes then, misty with pain, or his hands as he worked with the bellows, a finger broken, sores on his thin wrists. [10] (37).

These lines speak of his serious introspection in that little image of "blacksmith's shop" through circular movement of time which starts with the memory of childhood wrapped in the burnt and black image of blacksmith's shop. The colour (black) and the place (blacksmith's shop) signify the childhood phase as a painful one which has a strong impact on the space-time of life that modified his vision of life. And suddenly a kingfisher swoops past above his head, calling.
The "calling" is low in tone but it is a kind of painful cry of the poets voice with "was it a vision or a waking dream" - kind of tone and the feeling which staggers with pain of the present in the lines:

\section{The morning wandered about at random, Neither real nor fiction \\ The ruins of my grandmother's tales \\ Where my voice trembled at the edge of things. [10] (37).}

But the root of its small cry is way back in its childhood. The face of the past is dead while the vision is still fresh in the eye of the present which pains him now. He says:

\section{The blacksmith's shop is gone now, And childhood sits in shadow \\ Like an eye in the face that is dead. [10] (37).}

And he visualizes the future which is a bleak, "invisible boundary." He compares the future with "a dead turtle" which symbolizes the corpse of his childhood that went on in isolated confines. The poem ends in silence and defeat in spite of strains of desperation. In a defeated voice he retires:

\section{....into one morning, in which \\ miracles don't happen. Just the desperation \\ of standing at some invisible boundary \\ without being able to get past it. [10] (37).}

So the only "small cries" in the poem are the "crackle" in the blacksmith's shop and the "calling" of the kingfisher the roots of which are in the emotional background. They fit into the native landscape of the poet. So in each poem the spiritually, mentally and psychologically fatigued poet returns from the haunting absences and deprivation to the solacing abode of the native landscape thus constructing a picture of his voice between the juxtaposed subjects. This is witnessed in the following lines:

"Each of Mahapatra's poems that speaks about the poetic process brings with it a comprehensive image of the poet's perilous relation with the dark powers and integrates his 'return' from the absences. Between the dark powers and this life, between myth and the ruins, between silence and speech, between the encounter and the moment stands the form, like a door that belongs neither to the house nor to the world outside." [14] (143).

In the poem "Moving" he experiments the technique of linear movement of time. Through this passionate movement Mahapatra strips himself naked in every poem until he himself becomes a landscape. The tone in the poem shows the poet's agony about its movement towards an impending disaster. The linear movement of the history of Orissa progressed on the avenues of Hinduism which practices idol worship and the people express their reverence by various rituals. Orissa is a land of temples and Hindu rituals. Many of Mahapatra's poems portray these practices and in every poem the poet is silently critical of the practices as futile since they have not rescued his land from the chronic natural calamities and also 
the communal disharmony.

The poem "Moving" is a good example for the interpretation of the impact of the cultural practices on the linear movement of time and its strong influence on the poet's life which is flanked by the parallel movement of the two cultures. The first stanza opens with the procession of drummers moving forward with the huge clay idol of Goddess Durga:

\section{Drummers on an autumn day, rain hammering \\ on the deep stillness of the valley [17] \\ (Mahapatra: 1976: 26).}

The sound, the movement, the season and the shallowness indicate a hopeless and an empty destination. The images "the autumn day" and "rain hammering" speak of the bleak and uncertain future and grief to where time progresses and also grave departure of something dear. "The stillness of the valley" means that his land is isolated from truth and prosperity. These drummers themselves announce the autumn of life. Rain indicates tears and this is announced by a great noise hammering on the drum. It also symbolizes the end of something. It evokes the "tom tom" in Emperor Jones.

There are layers of implications in the first stanza which is a strong image of a landscape in which we see an emotional movement of thought with pain. The image "deep stillness of the valley" has a deep meaning denoting an Indian musical instrument Tabala or some other drum used in the Hindu rituals and also the touching image of "rain hammering" shows the pain of the landscape of the poet's heart.

The second stanza opens with the dark and brittle image of "ten-armed clay Durga" which the people sternly believe will lead to prosperity. It is an unnatural image having ten hands as if it were to do miracles. The history and the "mythic past" framed in the movement of time have been moving towards future with the same beliefs and with the same hopeless practices that never led the land to prosperity. The last stanza expresses that men are committed to work for the goddess from dawn to dusk keeping pace with the time but the phrase "carried slowly" shows a contrary picture that in spite of this service the land still lies in poverty. Mark this grim picture in the stanza:

\section{The ten-armed clay Durga \\ framed in the mythic past}

carried slowly by twenty-four tired men. [17] (26).

Like a tear that falls in silence he shows his pain of isolation in the line "Moving surrounds us." In the poem the line itself is isolated from all the other stanzas. Everything around him moves but this once again denotes silence, estrangement, isolation and transitoriness. The image of the "tar melting" speaks of the questionable practices of the temple priests melt the way they lead the pilgrims bleak it. The poet has a great consideration for silence in this poem. Silence according to him should speak volumes as "still waters run deep" but here the silence, unlike the silence of Christ and Buddha, is dump and futile and insubstantial. The deformed eye of the God doesn't capture anything.

\section{CONCLUSION}

Mahapatra's literary journey progresses in the frame of space and time of his life and experience. Cleft between two faiths the Mahapatra falls into Isolation. In this exile poet recalls his painful experiences of the past in a circular introspection. In the process of this ordeal he is engulfed by an abstract vastness of a space of memories that struggles to expand. He symbolizes himself as a door - indicating a dividing line between the haunting past and uncertain future and a painful presence of a ceaselessly opening and closing door of lyrical pathos. His truth is relative to his experience of the events examined in the dynamics of time. With the harmony of his knowledge of science, his experience of life, a deepest understanding with imagination; which "is more important than knowledge" [18] (Herweck 2009: 10) and faith which according to Leo Tolstoy is "the force of life" [19] (Phong 2001: 308) Mahapatra defines himself as a miniscule entity of time in this vast universe. He accepts his limits as a mortal. The argument can be summed up in the words of Einstein:

"Once we accept our limits, we can go beyond them." [20] (Bogunovic 2013: 122).

\section{REFERENCES}

[1] D. H. Griffin, Alexander Pope: The Poet in Poems, New Jersey: Princeton University Press, 1978, p. 152.

[2] P. Schneider, How the Light Gets In: Writing as a Spiritual Practice, Oxford, 2013, p. 9

[3] K. Larsen, Stephen Hawking: A Biography, Connecticut: Greenwood Press, 2005, p. 42.

[4] D. Mills, Atheist Universe: The Thinking Person's Answer to Christian Fundamentalism, California: Ulysses Press, 2005, p. 100

[5] M. Born, Einstein's Theory of Relativity, Toronto: Dover Publications Inc., 1962, p. 5 .

[6] J. Mahapatra, Whiteness of a Bone, New Delhi: Viking Penguin Books India, 1992, p. 14

[7] S. Kopuri, "The cleft identity of Jayanta Mahapatra at the end of words," in Identity, Difference and Belonging, Dina Mansour, ed. 2014, vol. 1, pp. 125-326.

[8] A. Roughley, Reading Derrida Reading Joyce, Florida: University Press of Florida, 1999, p. 92.

[9] C. H. Hinnant, Steel of the Mind: Samuel Johnson and Critical Discourse, Massachusetts: Associated University Presses Inc., 1994, p. 203.

[10] J. Mahapatra, Shadow Space, Kottayam: DC Books, 1997, p. 72.

[11] J. Milton, Paradise Lost: A Poem in Twelve Books, London: T. Spilsbury \& Son, 1670, p. 1.

[12] J. Mahapatra, Random Descent, Bhubaneswar: Third Eye Communications, 2005, p. 13.

[13] C. Beech, The Cambridge Introduction to Twentieth-Century American Poetry, Cambridge University Press: Cambridge, 2003, p. 40.

[14] B. King, "Jayanta Mahapatra's Poetic: The shapes of solitude," in The Poetry of Jayanta Mahapatra: Some Critical Considerations, M. Praead, Ed. New Delhi: B. R. Publishing Corporation, 2000, Ch. 1, pp $1-8$.

[15] J. Gribbin, "An anniversary of some gravity,” New Scientist, vol. 116, no. 1586, pp. 44-50, November 1987.

[16] Betsy and T. Melvin. Robert Frost's New England, Hanover: University Press of New England, 2000, p. 14.

[17] J. Mahapatra, A Rain of Rites, Athens: The University of Georgia Press, 1976, p. 26

[18] D. Herweck, Albert Einstein and His Theory of Relativity, Mankato: Compass Point Books, 2009, p. 10.

[19] N. X. Phong, Hope and Vanquished Reality, New York: Xlibris Corporation, 2001, p. 308.

[20] D. P. Bogunovic, Heavenly Wisdom: Talent, Imagination, Creativity and Wisdom, Bloomington: Author House, 2013, p. 122 


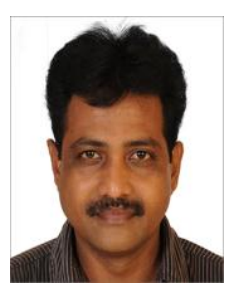

Sreekanth Kopuri is an Indian English Poet, he was born in Machilipatnam, India where he had his schooling in Nirmala High School and graduation in Commerce from Noble College. After his masters study from Andhra University, he taught poetry at Dravidian University India. Apart from being an Assistant Professor in Sri Vasavi Institute of Engineering \& Technology, he is also a PhD scholar on the poetry of Jayanta Mahapatra in Sri Venkateswara University. $\mathrm{He}$ has a close association with Jayanta
Mahapatra's family for long. He has come out with an anthology of his poems "The Shadows." His poems were published in India and abroad. He presented his research papers in many reputed universities like Oxford University United Kingdom, University of Caen France, Banja Luka University Bosnia and Herezegovina, University of Gdanski Poland and others. He was the recipient of Dr. J.K. International Award for 2014, Man of the Year Award 2011, Editor's Choice Award 2009 from India for his achievements in poetry. Sreekanth Kopuri presently Lives in Machilipatnam dividing his time between teaching and creative writing. His areas of interest are Silence, Holocaust Poetry, Quantum Art Poetry and Christian Literature. 